\title{
SKEMA SOLUSI YANG DIPILIH MAHASISWA DALAM MENYELESAIKAN TEORI GRAF SUB ISOMORFIK DITINJAU DARI TEORI OPERATOR KONSTRUKTIF
}

\author{
Puput Suriyah $^{1}$ \\ IKIP PGRI Bojonegoro, puput.suriyah@ikippgribojonegoro.ac.id ${ }^{1}$ \\ Received : 14 September 2018, Revised : 7 Oktober 2018, Accepted : 17 Oktober 2018 \\ (c) Mathematics Education Unugiri 2018
}

\begin{abstract}
This study aims to describe the solution scheme chosen by students in understanding the isomorphic relation of a graph. The method used in this study is a qualitative research method. Subjects in this study amounted to 35 students from the Mathematics Education Study Program of PGRI Bojonegoro in the fourth semester of the 2017/2018 academic year. Test questions related to the isomorphic understanding of a graph were given to thirty-five students, then six students were selected to be interviewed. Data analysis was carried out by using triangulation. it was done by comparing the data from video interviews and test results data. This is done to ensure the validity and reliability of research. The result of the study shows that the elements of disclosure in the description of student answers were various. It shows that the existence of an operative scheme that is a diverse problem-solving. There was a proof of the gravity of a graph by adding vertices to both graphs comparing and making sure that the numbers are the same, reviewing adjacent, and some are equipped with a matrix. In the element of impact there are those who write conclusions and there are some who do not. Variations in the solution scheme used by students can be used as an evaluation of learning that students are unique so there is a need for continuous innovation related to students center learning.
\end{abstract}

\section{Keywords : Solution Scheme, Isomorphic Graph, Constructive Operator Theory}

\begin{abstract}
Abstrak
Penelitian ini bertujuan untuk mendeskripsikan skema solusi yang dipilih oleh siswa dalam memahami hubungan isomorfik suatu graf. Metode yang digunakan dalam penelitian ini adalah metode penelitian kualitatif. Subyek dalam penelitian ini berjumlah 35 siswa dari Program Studi Pendidikan Matematika PGRI Bojonegoro pada semester keempat tahun akademik 2017/2018. Pertanyaan tes yang berkaitan dengan pemahaman isomorfik grafik diberikan kepada tiga puluh lima siswa, kemudian enam siswa dipilih untuk diwawancarai. Analisis data dilakukan dengan menggunakan triangulasi. itu dilakukan dengan membandingkan data dari wawancara video dan data hasil tes. Ini dilakukan untuk memastikan validitas dan reliabilitas penelitian. Hasil penelitian menunjukkan bahwa elemen pengungkapan dalam deskripsi jawaban siswa beragam. Ini menunjukkan bahwa keberadaan skema operasi yang merupakan pemecahan masalah yang beragam. Ada bukti gravitasi grafik dengan menambahkan simpul ke kedua grafik yang membandingkan dan memastikan bahwa angka-angkanya sama, meninjau yang berdekatan, dan beberapa dilengkapi dengan matriks. Dalam elemen dampak ada orang yang menulis kesimpulan dan ada sebagian yang tidak. Variasi dalam skema solusi yang digunakan oleh siswa dapat digunakan sebagai evaluasi pembelajaran bahwa siswa adalah unik sehingga ada kebutuhan untuk inovasi berkelanjutan yang terkait dengan pembelajaran pusat siswa.
\end{abstract}

Kata kunci:Skema Solusi, Isomorfik Graf,Teori Operator Konstruktif 


\section{Pendahuluan}

Kemampuan memecahkan masalah merupakan sasaran pokok dan kebutuhan utama dalam belajar matematika. Dalam hal ini kemampuan yang dimaksud antara lain memahami masalah, merancang dan menyelesaikan model matematika serta menginterpretasikan solusi yang diperoleh [1].

Soal cerita termasuk di dalamnya soal open ended harus diterjemahkan atau diinterpretasikan secara terperinci untuk mendapatkan solusi yang diinginkan. Menemukan nilai, mendefinisikan variabel, memilih operasi hitung, menentukan formula, membuat ilustrasi gambar, bagan dan menetapkan langkah solusi adalah contohcontoh bahasa matematika. Misalnya Downton [2], menggunakan kalimat-kalimat berikut untuk tingkat kesulitan yang berbeda: (1) easy: "I have 12 cherries to share equally onto 3 plates. How many cherries will I put on each plate?"; (2) medium: I have 18 cherries to share equally onto 3 plates. How many cherries will I put on each plate?"; dan (3) challenge: I have 48 cherries to share equally onto 3 plates. How many cherries will I put on each plate?"

Menurut Pascual-Leone et al [3] dan Mampouw et al [4], bahwa soal open-ended dapat mencerminkan skema kognitif peserta didik. Penelitian ini menggunakan pendekatan Teori Operator Konstruktif dalam rangka menganalisis skema solusi yang dipilih mahasiswa. Piaget merupakan ilmuwan yang memberikan kontribusi besar terkait perkembangan kognitif, yang mana bergantung pada pertumbuhan biologis, pengalaman dengan lingkungan fisik, pengalaman dengan lingkungan sosial dan ekuilibrasi [5]. Perkembangan kognitif menurut Piaget dibagi menjadi empat tahapan diantaranya: sensori motor (0-2 tahun), pra operasi (2-7 tahun), operasi konkrit (7-11 tahun) dan operasi formal (11 tahun sampai dewasa). Kemampuan memproses informasi pada anak-anak akan bertambah seiring bertambahnya usia [5], tetapi tidak menjamin bahwa semakin banyak informasi akan membuat pikiran mereka lebih maju [6].
Pascual-Leone [3,7] menyatakan bahwa satuan informasi pada Teori Operator Konstruktif dinyatakan dari sudut pandang subyek yaitu operasi mental. Operasi mental adalah operasi yang berada di dalam pikiran seseorang. Operasi mental terjadi akibat adanya operator. Operator ini bekerja di dalam pikiran atau di dalam otak sehingga seseorang mengalami proses mental dalam mengembangkan pikiran karena menerima informasi. Operator konstruktif berarti operator yang mengkonstruksi proses mental sehingga skema kognitif berkembang.

Penelitian ini aPiaget memusatkan pengertian skema pada perkembangan dan perubahan [8]. Skema berkembang dan berubah karena kognisi seseorang perlu diorganisasikan ketika beradaptasi dengan informasi baru. Proses adaptasi berlangsung dalam dua cara yakni asimilasi dan akomodasi. Pada asimilasi, informasi baru cocok dengan skema yang sudah ada sehingga memperkuat struktur kognitif yang sudah ada. Pada akomodasi, informasi baru tidak cocok dengan skema yang sudah ada sehingga struktur kognitif harus berubah. Jadi pada asimilasi terdapat skema yang berkembang sedangkan pada akomodaso terdapat skema yang berubah. Kognisi seseorang menjadi seimbang setelah mengalami proses adaptasi dan dengan demikian dapat dikatakan telah terjadi perkembangan kognitif.

Pada Teori Operator Konstruktif, unsur fungsional merupakan unsur yang indiakatornya memahami konteks soa yang diberikan. Unsur pengungkapan merupakan cara/metode/solusi/skema operatif yang disajikan dalam pemecahan masalah. Unsur dampak merupakan poin penafsiran terhadap skema operatif yang ada pada unsur pengungkapan. Menurut Fischbein [10], soal open ended memuat masalah yang harus diselesaikan dimana setiap peserta didik akan memberikan skema solusi berdasarkan cara berpikirnya.

Penelitian ini merupakan penelitian kualitatif. Instrumen utama dalam penelitian ini adalah peneliti sendiri, sedangkan 
instrumen tambahan dalam penelitian ini adalah soal tes dan wawancara. Subjek dalam penelitian ini sebanyak 35 mahasiswa dari Program Studi Pendidikan Matematika IKIP PGRI Bojonegoro. Subjek yang terpilih untuk diwawancarai adalah yang mewakili dari skema solusi dipilih berdasarkan klasifikasi ditinjau dari teori operator konstruktif. Purposive sampling yaitu pemilihan sampel berdasarkan tujuan merupakan teknik pemilihan sampel yang dilakukan.

Analisis data merupakan proses mencari dan menyusun secara sistematis data yang diperoleh dari hasil pekerjaan tertulis subjek penelitian dengan cara mengorganisasikan data ke dalam kategori, menjabarkan ke dalam unitunit yang penting dan yang akan dipelajari, dan membuat kesimpulan sehingga mudah dipahami oleh diri sendiri atau oleh orang lain. [10] Analisis data dilakukan terbatas pada apa yang dikerjakan mahasiswa (baik lisan maupun tulisan). Proses analisis data menggunakan model Miles dan Huberman [10] yang dilakukan dengan langkah-langkah sebagai berikut: reduksi data, penyajian data, penarikan kesimpulan

Para mahasiswa mengerjakan tentang keisomorfikan dari suatu graf pada lembar kerja tanpa adanya interupsi. Jawaban mahasiswa dari soal tersebut kemudian dianalisis berdasarkan kemunculan unsur fungsional, pengungkapan dan dampak serta bagaimana unsur-unsur tersebut dinyatakan.

\section{Pembahasan}

Jawaban yang diberikan mahasiswa menggambarkan bagaimana skema solusi yang dipilih mahasiswa dalam memecahkan masalah sub isomorfik pada teori graf. Skema solusi dapat dijabarkan melalui teori operator konstruktif diantaranya unsur fungsional, unsur pengungkapan dan unsur dampak. Dalam hal ini peneliti mendeskripsikan berbagai variasi jawaban mahasiswa pada unsur pengungkapan. Soal yang diberikan kepada mahasiswa yaitu : "Apakah graf berikut saling isomorfik? Jelaskan."

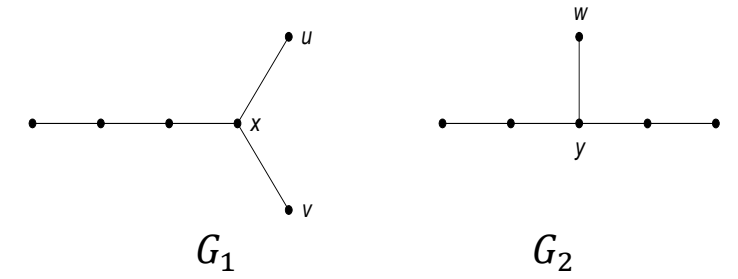

Gambar 1. Soal tes terkait graf isomorfik

Jawaban benar berdasarkan soal yang tertera pada Gambar 1 yaitu:

$$
\begin{aligned}
& G_{1}=\left[\begin{array}{llllll}
0 & 1 & 0 & 0 & 0 & 0 \\
1 & 0 & 1 & 0 & 0 & 0 \\
0 & 1 & 0 & 1 & 0 & 0 \\
0 & 0 & 1 & 0 & 1 & 1 \\
0 & 0 & 0 & 1 & 0 & 0 \\
0 & 0 & 0 & 1 & 0 & 0
\end{array}\right] \\
& G_{2}=\left[\begin{array}{llllll}
0 & 1 & 0 & 0 & 0 & 0 \\
1 & 0 & 1 & 0 & 0 & 0 \\
0 & 1 & 0 & 1 & 0 & 1 \\
0 & 0 & 1 & 0 & 1 & 0 \\
0 & 0 & 0 & 1 & 0 & 0 \\
0 & 0 & 1 & 0 & 0 & 0
\end{array}\right]
\end{aligned}
$$

Berdasarkan matriks ketetanggan pada $G_{1}$ dan $G_{2}$ jelas terlihat bahwa mempunyai nilai yang berbeda, bisa disimpulkan bahwa kedua graf tidak saling isomorfik. Berikut disajikan jawaban dari 5 mahasiswa terpilih berdasarkan purposive sampling (pengambilan sampel berdasarkan tujuan).

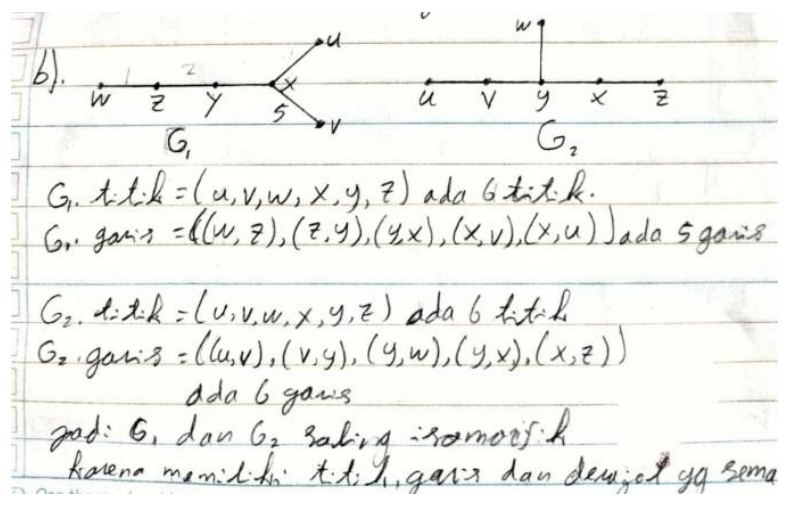




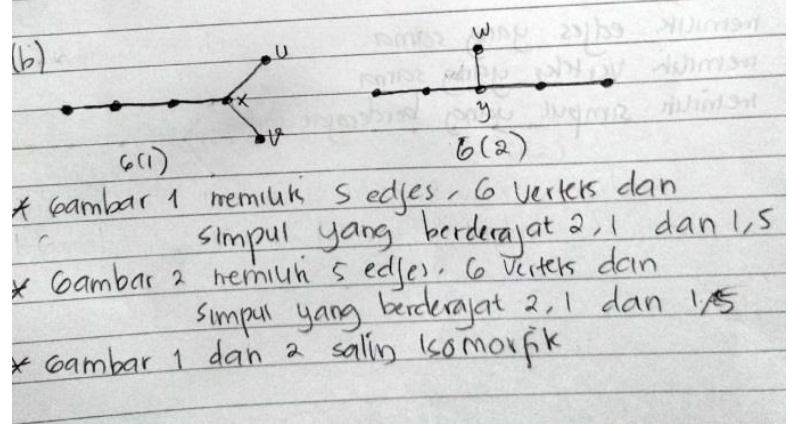

Gambar 2. Jawaban subjek 3 (atas) dan subjek 16 (bawah)

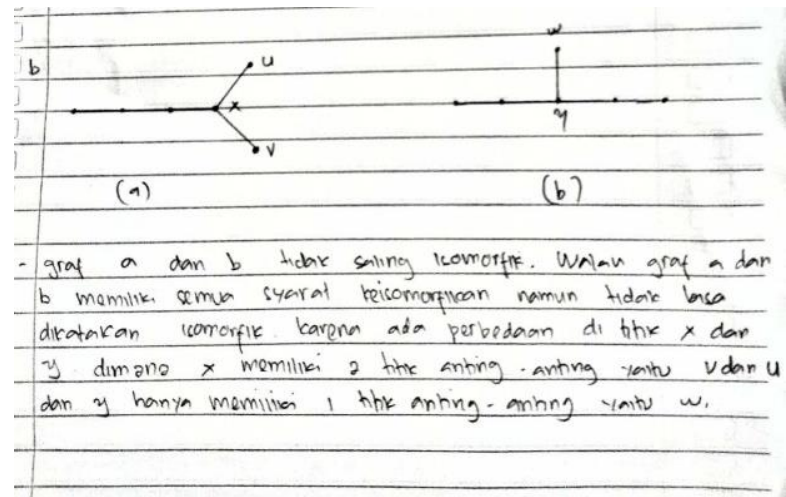

Gambar 3. Jawaban Subjek 6

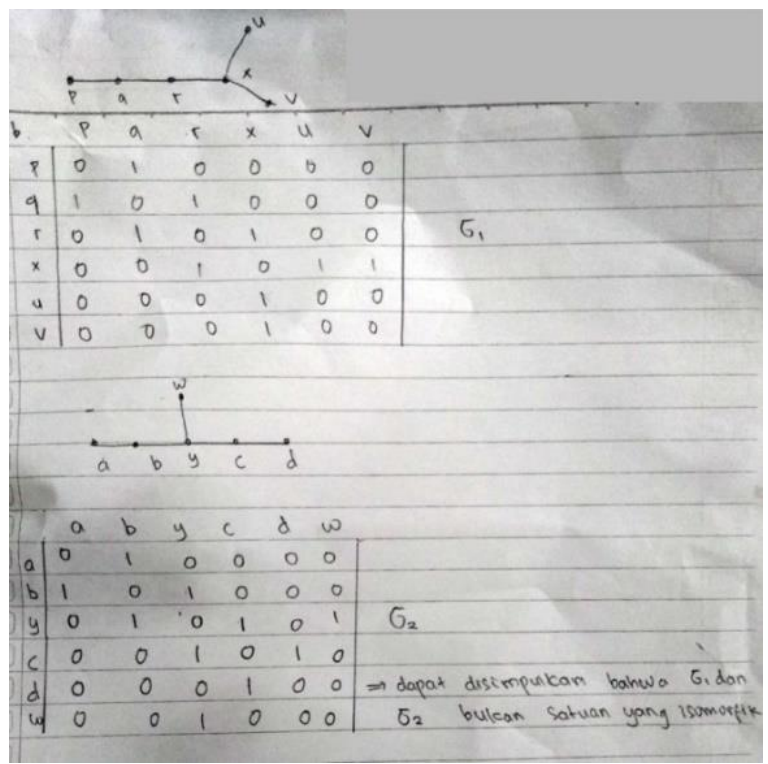

Gambar 4. Jawaban subjek 7

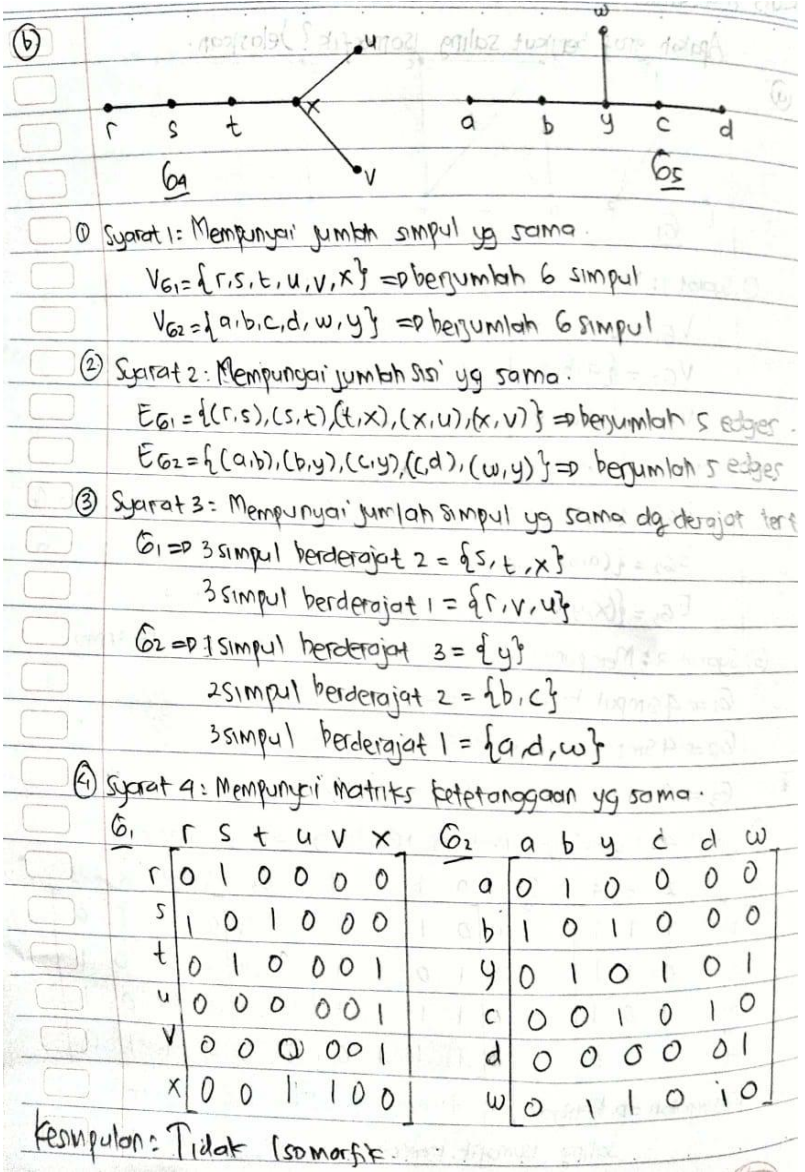

Gambar 5. Jawaban subjek 30

Berdasarkan jawaban dari 35 mahsiswa berikut Tabel 1 menggambarkan keseluruhan jawaban mahasiswa terkait pencantuman unsur-unsur skema menurut TCO.

Tabel 1. Pencantuman unsur-unsur skema menurut TCO

\begin{tabular}{lc}
\hline \multicolumn{1}{c}{$\begin{array}{c}\text { Unsur skema yang } \\
\text { muncul }\end{array}$} & $\begin{array}{c}\text { Frekuensi } \\
\text { jawaban }\end{array}$ \\
\hline $\begin{array}{l}\text { Fungsional, } \\
\text { pengungkapan dan } \\
\text { dampak }\end{array}$ & - \\
$\begin{array}{l}\text { Pengungkapan dan } \\
\text { dampak saja }\end{array}$ & 25 \\
Pengungkapan saja & 10 \\
\hline \multicolumn{1}{c}{ Jumlah } & 35 \\
\hline
\end{tabular}

Dari Tabel 1 terlihat bahwa tidak ada satupun mahasiswa yang memunculkan unsur fungsional. Berdasarkan wawancara yang 
dilakukan, mereka tidak mencantumkan unsur fungsional karena menurut mereka soal yang diberikan bukan soal cerita. Unsur fungsional menggambarkan visi dari soal yang akan dilakukan pemecahan masalah. Padahal soal open ended seperti di atas jika dikerjakan berdasarkan langkah-langkah pemecahan yang dideskripsikan para ahli seperti langkah pemecahan yang populer berdasarkan Polya atau yang dikemukakan oleh Bransford dan Stein [6], maka ketiga unsur yaitu fungsional, pengungkapan dan dampak akan termuat di dalamnya.

Berdasarkan Mahmudi [11] mengatakan bahwa soal terbuka (open ended problem) adalah soal yang mempunyai banyak solusi dan strategi penyelesaian. Soal yang bersifat terbuka memiliki tujuan membantu mengembangkan dengan maksimal berfikir kreatif sesuai kemampuan yang dimiliki setiap siswa [12]. Dengan demikian, siswa dibiasakan untuk berpikir tidak monoton dan tidak terpaku dengan contoh yang diberikan oleh guru. Definisi inilah yang belum dipahami benar oleh para mahasiswa. Mereka belum terbiasa mengikuti langkah-langkah pemecahan masalah menurut ahli. Jika itu dilakukan, pasti ketiga unsur tersebut akan tercantum di pengerjaan atas pemecahan masalah yang mereka deskripsikan.

Pembahasan berikutnya adalah unsur pengungkapan. Skema solusi yang utama dari penyelesaian masalah terletak di unsur ini. Deskripsi dari masing-masing subjek terperinci pada paragraf berikutnya, mulai dari subjek 3, subjek 16, subjek 6, subjek 7 dan subjek 30 . Unsur pengungkapan berkaitan dengan kondisi atau situasi pada soal open ended yang mendorong skema figuratif dan operator teraktivasi[13].

Berdasarkan subjek 3 jawaban yang diberikan salah Seharusnya jawaban benar pada unsur dampak (kesimpulan) adalah tidak saling isomorfik. Pemahaman subjek 3 terkait graf isomorfik terbatas pada graf yang mempunyai jumlah simpul (vertex) sama, jumlah sisi (edges) sama. Unsur pengungkapan oleh subjek 3 pada G1 yaitu, titik yang ada antara lain $\mathrm{u}, \mathrm{v}, \mathrm{w}, \mathrm{x}, \mathrm{y}, \mathrm{z}$ serta edges $\mathrm{G} 1$ antara lain $(\mathrm{w}, \mathrm{z}),(\mathrm{z}, \mathrm{y}),(\mathrm{y}, \mathrm{x}),(\mathrm{x}, \mathrm{v}),(\mathrm{x}, \mathrm{u})$. Begitu pula pada titik yang ada pada G2 yang sama, dan edges pada G2 antara ; ain $(\mathrm{u}, \mathrm{v}),(\mathrm{v}, \mathrm{y}),(\mathrm{y}, \mathrm{w})$, $(\mathrm{y}, \mathrm{x}),(\mathrm{x}, \mathrm{z})$. Begitu pula pada jawaban subjek 16 pemahamannya hanya sebatas pada jumlah simpul dan sisi yang sama dalam menganalisis suatu graf. Beberapa syarat tersebut belum cukup menjamin, pemeriksaan visual perlu pula dilakukan dalam menentukan keisomorfikan suatu graf. Pada jawaban tersebut unsur dampak muncul, tetapi jawaban yang diberikan salah.

Unsur pengungkapan yang dideskripsikan subjek 6, bahwa graf tersebut tidak saling isomorfik. Jawaban yang dituliskan benar. Subjek 6 menuliskan bahwa syarat keisomorfikan semuanya ada, namun ada perbedaan di titik $\mathrm{x}$ dan $\mathrm{y}$ dimana $\mathrm{x}$ memiliki 2 titik anting-anting yaitu $v$ dan $u$, serta y hanya memiliki 1 titik anting-anting yaitu w. Alasan yang diberikan pada jawaban di atas belum tepat. Seharusnya dengan jawaban akhir (unsur dampak) bahwa graf tidak isomorfik, syarat keisomorfikan tidak semuanya ada.

Jawaban yang diberikan subjek 7 menggunakan alternatif matriks ketetanggaan, dengan memperhatikan dan membandingkan kedua matriks maka kesimpulan yang dibuat bisa langsung diterima kebenarannya. Penentuan di awal vertex untuk mengisi baris dan kolom antara satu graf dengan graf lainnya memang sedikit membingungkan, tetapi jika sudah menemukan pasangannya maka sangat mudah langkah berikutnya untuk mengisi kolom dengan angka 1 dan 0 . Angka 1 menunjukkan ketetanggaan antara titik pada baris dan kolom yang saling bertemu, dan angka 0 untuk vertex yang tidak saling bertemu.Unsur dampak yang dituliskan benar. Jawaban ini cukup singkat dan jelas untuk menentukan keisomorfikan suatu graf.

Jawaban yang diberikan subjek 30 dideskripsikan dengan lengkap. Selain menggunakan matriks ketetanggaan, subjek 30 juga menjelaskan masing-masing vertex di G1 $(\mathrm{r}, \mathrm{s}, \mathrm{t}, \mathrm{u}, \mathrm{v}, \mathrm{x})$ dan vertex di G2 (a, b, c, d, w, 
y), sisi yang ada di G1 antara lain : $(\mathrm{r}, \mathrm{s}),(\mathrm{s}, \mathrm{t})$, $(\mathrm{t}, \mathrm{x}),(\mathrm{x}, \mathrm{u}),(\mathrm{x}, \mathrm{v})$, serta sisi yang ada di G2 antara lain : (a,b), (b,y), (c,y), (c,d), (w,y ) dimana jumlah sisi (edges) pada G1 dan G2 yaitu 5. Kemudian subjek 30 mendeskripsikan (unsur pengungkapan) pada jumlah simpul yang sama dengan derajat tertentu. Pada G1 ada 3 simpul yang berderajat 2 yaitu $(\mathrm{s}, \mathrm{t}, \mathrm{x}) ; 3$ simpul berderajat $1(\mathrm{r}, \mathrm{v}, \mathrm{u})$. Kemudian pada G2, 1 simpul berderajat 3 (y); 2 simpul berderajat 2 (b,c); dan 3 simpul berderajat 1 (a,d,w). Jawaban yang diberikan subjek 30 sangat jelas dan terperinci.

Skema operatif dalam solusi mahasiswa untuk menunjukkan keisomorfikan kedua graf tersebut bervariasi antara satu dan yang lainnya. Ada yang menghitung masing-masing vertex (titik), edges (sisi) maupun degree (derajat), juga mengkaitkan simpul-simpul atau titik-titik yang saling bertetangga (adjacent). Subjek lainnya memberikan solusi dengann singkat dan tepat yaitu menggunakan matriks. Ada pula subjek lain yang mendeskripsikan solusi-solusi di atas secara lengkap.

Unsur berikutnya yaitu unsur dampak. Unsur ini berkaitan dengan akibat aksi skema operatif yang dilakukan mahasiswa. Berikut Tabel 2 menyajikan variasi kemunculan unsur dampak dari jawaban mahasiswa.

Tabel 2. Variasi kemunculan unsur dampak

\begin{tabular}{lcc}
\hline \multicolumn{1}{c}{$\begin{array}{c}\text { Perlakuan terhadap hasil } \\
\text { perhitungan }\end{array}$} & $\begin{array}{c}\text { Frekuensi } \\
\text { jawaban }\end{array}$ \\
\hline Ada kesimpulan : & - Benar & 25 \\
& - Salah & 3 \\
Tidak ada kesimpulan : - & 4 \\
Benar & -Salah & 3 \\
\hline Jumlah & & 35 \\
\hline
\end{tabular}

Tabel 2 menggambarkan tiga cara melakukan pembuktian terkait Graf G1 dan Graf G2. Sebagian besar mahasiswa memahaminya dan mendeskripsikan maknanya sebagai kesimpulan (conclusion). Ada 28 mahasiswa yang membuat kesimpulan, 3 diantaranya memberikan jawaban yang salah atas soal yang diberikan. Ada 7 mahasiswa yang tidak memberikan kesimpulan, dimana 3 diantaranya jawabannya salah.

\section{Penutup}

Hasil penelitian menunjukkan bahwa pada unsur fungsional tidak ada satu pun mahasiswa yang mencantumkannya. Ini bisa sebagai evaluasi kepada pendidik dalam hal ini dosen bahwa mahasiswa perlu diberi wawasan yang lebih terkait soal open ended beserta bagaimana pemecahan masalah yang sesuai dengan langkah-langkah yang sudah dikemukanan oleh para ahli, misalkan saja Polya.

Pada unsur pengungkapan pada deskripsi jawaban mahasiswa bervariasi, hal ini menunjukan adanya skema operatif yakni pemecahan masalah yang beragam. Ada yang membuktikan keisomorfikan graf dengan menjumlah simpul/titik (vertex) pada kedua graf kemudaian membandingkan dan memastikan bahwa jumlahnya sama, meninjau ketetanggaan (adjacent), dan ada juga yang dilengkapi dengan matriks. Pada unsur dampak ada yang menuliskan kesimpulan dan ada beberapa yang tidak.

Variasi skema solusi yang dipakai mahasiswa bisa dijadikan sebagai evaluasi pembelajaran bahwa peserta didik itu unik sehingga perlu adanya inovasi secara menerus terkait pembelajaran yang berpusat kepada peserta didik dalam hal ini mahasiswa. Inovasi bisa dilakukan melalui metode, teknik, strategi yang diterapkan di kelas. Selain itu, pembelajaran yang berbasis contextual learning sangatlah dibutuhkan oleh para mahasiswa dalam rangka mempermudah dalam mengkonstruk pengetahuan. Hal tersebut bisa membuka ruang bagi peneliti lain untuk melakukan penelitian selanjutnya.

\section{Ucapan Terimakasih}

Artikel hasil dari penelitian yang dilakukan ini didukung sepenuhnya oleh LPPM (Lembaga Penelitian dan Pengabdian Kepada Masyarakat) IKIP PGRI Bojonegoro. 


\section{Referensi}

[1] Direktorat Jenderal Pendidikan Dasar dan Menengah, Peraturan Menteri Pendidikan Nasional Republik Indonesia Nomor 22 Tahun 2006 Tentang Standar Isi Untuk Satuan Pendidikan Dasar dan Menengah. (2006)

[2] Dontown, Ann. Links Between Children's Understanding of Multiplication and Solution Strategies For Division, Proceedings of the $31^{\text {st }}$ Annual Conference of the Mathematics Education Research Group of Australasia M. Goos, R. Brown, \& K. Makar (Eds.), CMERGA Inc. (2008).

[3] Pascual-Leone, J.,J.Johnson, A. Agostino. Mental Attention, Multiplication Structures, and the Causal Problem of Cognitive Development. In Ferrari, M., Vuletic, L (eds). Developmental Relations among Mind, Brain and Emotion. Springer. (2010).

[4] Mampouw, Helti Lygia., Agung Lukito, St. Suwarsono. Internalization of Multiplication and Division Concepts in A Neo-Piagetian Perspective. Proceeding $2014 \quad$ International Conference on Research, Implementation, and Education of Mathematics and Science (ICRIEMS). (2014). Yogyakarta State University.

[5] Schunk, Dale . Learning Theoris: An Educational Perspective, $6^{\text {th }}$ ed. (terj.). Yogyakarta: Pustaka Belajar. (2012)

[6] Santrock, John W. 2011. Psikologi Pendidikan. Jakarta: Prenada Media Group.
[7] Pascual-Leone. J., E.M.R. Escobar, J. Johnson. Logic: Development of Logical Operation. In W. Hirstein (section ed.). Encyclopedia of Human Behavior. New York: University Press. (2012)

[8] Marshall, Sandra P. Schemas in Problem Solving. New York: Cambridge University Press. (1999)

[9] Fishbein, Efraim.Intuitions and Schemata in Mathematical Reasoning. Dalam Dina Tirosh (ed.) Form of Mathematical Knowledge Learning and Teaching with Understanding. Kluwer Academic Publishers. (1999)

[10] Sugiyono. Metode Penelitian Pendidikan. Pendekatan Kuantitatif, Kualitatif, dan R \& D. Bandung: Alfabeta. (2008)

[11] Mahmudi, Ali. Mengembangkan Soal Terbuka (Open Ended Problem) dalam Pembelajaran Matematika. Makalah Disajikan di Seminar Nasional Matematika dan Pendidikan Matematika yang Diselenggarakan oleh Jurusan Pendidikan Matematika FMIPA UNY Yogyakarta. (2008) 28 November.

[12] Suherman, Erman, dkk. Strategi Pembelajaran Matematika Kontemporer. Bandung: JICA UPI. (2003)

[13] Mampouw, H.L., Lukito, A., Suwarsono, St. Skema Solusi yang Dipilih Mahasiswa dalam Menyelesaikan Soal Cerita Ditinjau Dari Teori Operator Konstruktif. Prosiding Seminar Nasional Matematika dan Pendidikan Matematika FMIPA J UNESA 2015. (2015) 809-819. 25 April, Surabaya. 
